\title{
Whole intact rapeseeds or sunflower oil in high-forage or high-concentrate diets affects milk yield, milk composition, and mammary gene expression profile in goats
}

\author{
S. Ollier, C. Leroux, A. de la Foye, L. Bernard, J. Rouel, and Y. Chilliard ${ }^{1}$ \\ INRA, UR1213 Herbivores, Site de Theix, F-63122 Saint-Genès-Champanelle, France
}

\begin{abstract}
This study aimed to ascertain the response of goat mammary metabolic pathways to concentrate and lipid feeding in relation to milk fatty acid (FA) composition and secretion. Sixteen midlactation multiparous goats received diets differing in forage-to-concentrate ratio [high forage (HF) 64:36, and low forage (LF) 43:57] supplemented or not with lipids [HF with $130 \mathrm{~g} / \mathrm{d}$ of oil from whole intact rapeseeds (RS) and LF with $130 \mathrm{~g} / \mathrm{d}$ of sunflower oil $(\mathrm{SO})]$ in a $4 \times 4$ Latin square design. Milk yield, milk composition, FA profile, and FA secretion were measured, as well as the expression profiles of key genes in mammary metabolism and of 8,382 genes, using a bovine oligonucleotide microarray. After 3 wk of treatment, milk, lactose, and protein yields were lower with HF-RS than with the other diets, whereas treatment had no effect on milk protein content. Milk fat content was higher with the HF-RS and LF-SO diets than with the HF and LF diets, and SO supplementation increased milk fat yield compared with the LF diet. Decreasing the forage-to-concentrate ratio from 64:36 to 43:57 had a limited effect on goat milk FA concentrations and secretions. Supplementing the LF diet with SO changed almost all the FA concentrations, including decreases in medium-chain saturated FA and large increases in trans C18:1 and C18:2 isomers (particularly trans-11 C18:1 and cis-9, trans-11 conjugated linoleic acid), without significant changes in C18:0 and cis-9 C18:1, whereas supplementing the HF diet with RS led to a strong decrease in short- and medium-chain saturated FA and a very strong increase in C18:0 and cis-9 C18:1, without significant changes in trans C18:1 and conjugated linoleic acid. Despite the decreases in milk lactose and protein yields observed with HF-RS, and despite the decrease in milk medium-chain FA and the increase in C18 FA secretion with RS or SO supplementation, none of the dietary treatments had any effect on mammary mRNA expression of the key
\end{abstract}

Received January 7, 2009.

Accepted July 23, 2009.

${ }^{1}$ Corresponding author: chilliar@clermont.inra.fr genes involved in lactose (e.g., $\alpha$-lactalbumin), protein (e.g., $\beta$-casein), and lipid metabolism (e.g., lipoprotein lipase) after 3 wk of treatment. In addition, transcriptome analysis did not provide evidence of treatments inducing significant changes in the expression of specific genes in the mammary gland. However, 2-way hierarchical clustering analysis highlighted different global mammary expression profiles between diets, showing that the gene expression profiles corresponding to the same diet were gathered by common groups of genes. This experiment suggests that after 3 wk of dietary treatment, other factors, such as substrate availability for mammary metabolism, could play an important role in contributing to milk FA responses to changes in diet composition in the goat.

Key words: lactating goat, lipid supplementation, milk composition, mammary transcriptome

\section{INTRODUCTION}

Dairy foods are an important source of nutrients in the human diet. The nutritional quality of milk depends on its composition, particularly its fatty acid (FA) composition. Certain FA have potentially negative (saturated FA, C18:2n-6 when consumed in excess) or positive (cis-9 C18:1, C18:3n-3) effects on human health. However, the effect of some trans isomers of C18:1 or C18:2 on human health is still subject to debate, and different trans C18:1 isomers may have different effects (Shingfield et al., 2008). Ruminant milk FA composition can change significantly in response to feeding regimen, especially lipid supplements, which have variable effects depending on the lipid added and its interaction with the type and proportion of forage and concentrate in the diet (Chilliard et al., 2007).

Although milk proteins are largely synthesized in the mammary gland, milk FA have 2 different origins. The long-chain FA $(>\mathrm{C} 16)$ come from triacylglycerides or NEFA present in plasma, whereas the short- and medium-chain FA (C4 to C14) are synthesized de novo in the mammary gland, and $\mathrm{C} 16$ shares both origins. In the bovine, diets rich in starch and polyunsaturated FA causing milk fat depression (MFD) have also been 
shown to decrease the expression of almost all the studied genes encoding key mammary lipogenic enzymes, such as lipoprotein lipase (LPL), which is involved in FA uptake; acetyl-coenzyme A carboxylase- $\alpha$ (ACACA) and FA synthase (FASN), which are involved in de novo FA synthesis; stearoyl-coenzyme A desaturase (SCD), which is involved in FA desaturation; and glycerol phosphate acyltransferase and acylglycerol phosphate acyltransferase, which are involved in triglyceride synthesis (see Bernard et al., 2008, and Harvatine et al., 2009, for reviews). In goats, however, the scarce data available show less pronounced responses of key lipogenic gene expression to lipid-supplemented diets (Bernard et al., 2005a, 2005b, 2008, 2009a), possibly because goats rarely exhibit MFD (Chilliard et al., 2003, 2007). Until now, such studies have been performed on approximately 10 genes, and no data are available on the global gene expression profile in response to lipid supplementation. In this way, the availability of ruminant transcriptome tools has led to broader studies of the impact of nutritional factors on mammary gene expression. Hence, a recent study using an 8,379 bovine oligonucleotide microarray showed that 48 -h food deprivation led to a modulation of the expression of goat mammary genes, especially those involved in milk secretion, such as genes encoding major milk proteins or genes involved in FA metabolism (Ollier et al., 2007).

This study used 4 diets designed to change the milk yield or composition and FA composition of goats with 3 aims: first, to evaluate the effects of forage-toconcentrate ratio on dairy performance and mammary gene expression; second, to decrease saturated FA and increase cis-9 C18:1 content without increasing trans FA by adding whole intact rapeseeds to a hay-based diet (Kennelly, 1996); and third, to decrease saturated FA and increase trans FA by adding C18:2n-6-rich sunflower oil to a hay- and concentrate-based, starch-rich diet (Chilliard et al., 2007; Bernard et al., 2009b). To better understand the mechanisms that modulate milk yield and composition in response to feeding factors and milk fat secretion in response to changes in the type of FA used by the mammary gland (cis vs. trans FA), we used 2 complementary approaches to determine whether our dietary treatments were associated with simultaneous modifications of goat mammary gene expression to expected changes in the secretion of milk components: the first approach focused on 13 candidate genes chosen on the basis of their implication in milk component biosynthesis. Selected genes included genes encoding major milk protein and genes involved in FA uptake, FA synthesis, desaturation, triglyceride synthesis, and milk fat globule membrane constitution. The second approach corresponded to a transcriptome analysis using a bovine microarray to compare gene expression profiles between different diets after $3 \mathrm{wk}$ of treatment.

\section{MATERIALS AND METHODS}

\section{Animals and Experimental Diets}

Sixteen multiparous Alpine goats at peak lactation (51 $\pm 11 \mathrm{~d}$ postpartum at the beginning of the experiment) from the Lusignan experiment station (France) were offered 4 experimental diets according to a $4 \times$ 4 Latin square design with 4 animals per group. The goats were divided into 4 groups based on homogeneity of milk yield, parity, and genotype at the $\alpha_{S 1}-\mathrm{CN}$ locus, which has been shown to affect milk traits (Grosclaude et al., 1994), and FA composition (Chilliard et al., 2006). Each period lasted $28 \mathrm{~d}$. The first $7 \mathrm{~d}$ were for treatment adaptation, and over the last $21 \mathrm{~d}$, the goats were fed one of the experimental diets described in Table 1. The treatments were 1) an alfalfa hay-based diet, with goats receiving a mixture of concentrates (Centraliment, Aurillac, France) expected to give a 60:40 forage-to-concentrate ratio, designated high forage (HF); 2) this same HF diet with $460 \mathrm{~g} / \mathrm{d}$ of whole intact rapeseeds (RS; Centraliment), supplying $130 \mathrm{~g}$ of oil/d and substituting for corn grain, beet pulp, and rapeseed meal (HF-RS); 3) an alfalfa hay-based diet with goats receiving a mixture of concentrates expected to give a 40:60 forage-to-concentrate ratio, designated low forage (LF); and 4) this same LF diet with $130 \mathrm{~g} / \mathrm{d}$ of sunflower oil (SO; Huilerie de Lapalisse, Lapalisse, France) substituting for corn grain (LF-SO). The experimental diets were formulated to cover 110 to $120 \%$ of energy and 120 to $130 \%$ of protein digestible in the intestine (PDI) requirements (INRA, 1989). Alfalfa hay was offered ad libitum. Concentrate ingredients were allocated according to the milk yield of individual goats during the preexperimental period, and were mixed together and offered as 2 equal meals after the a.m. and p.m. milkings. Individual intakes (weight of distributed hay minus refused hay, and, rarely, concentrate refusals) were recorded $4 \mathrm{~d} / \mathrm{wk}$, and the chemical composition of feed ingredients was determined on pooled samples by using standard procedures (AOAC, 1997). Goats were housed in individual stalls with free access to water, and were cared for and handled in compliance with the INRA Animal Care Committee guidelines.

\section{Milk Sampling and Analysis}

The goats were milked daily at 0800 and $1600 \mathrm{~h}$ and milk yield was recorded three times weekly, but only measurements taken during the last week of each experimental period were analyzed statistically. Milk 
Table 1. Ingredient and chemical composition of the experimental diets

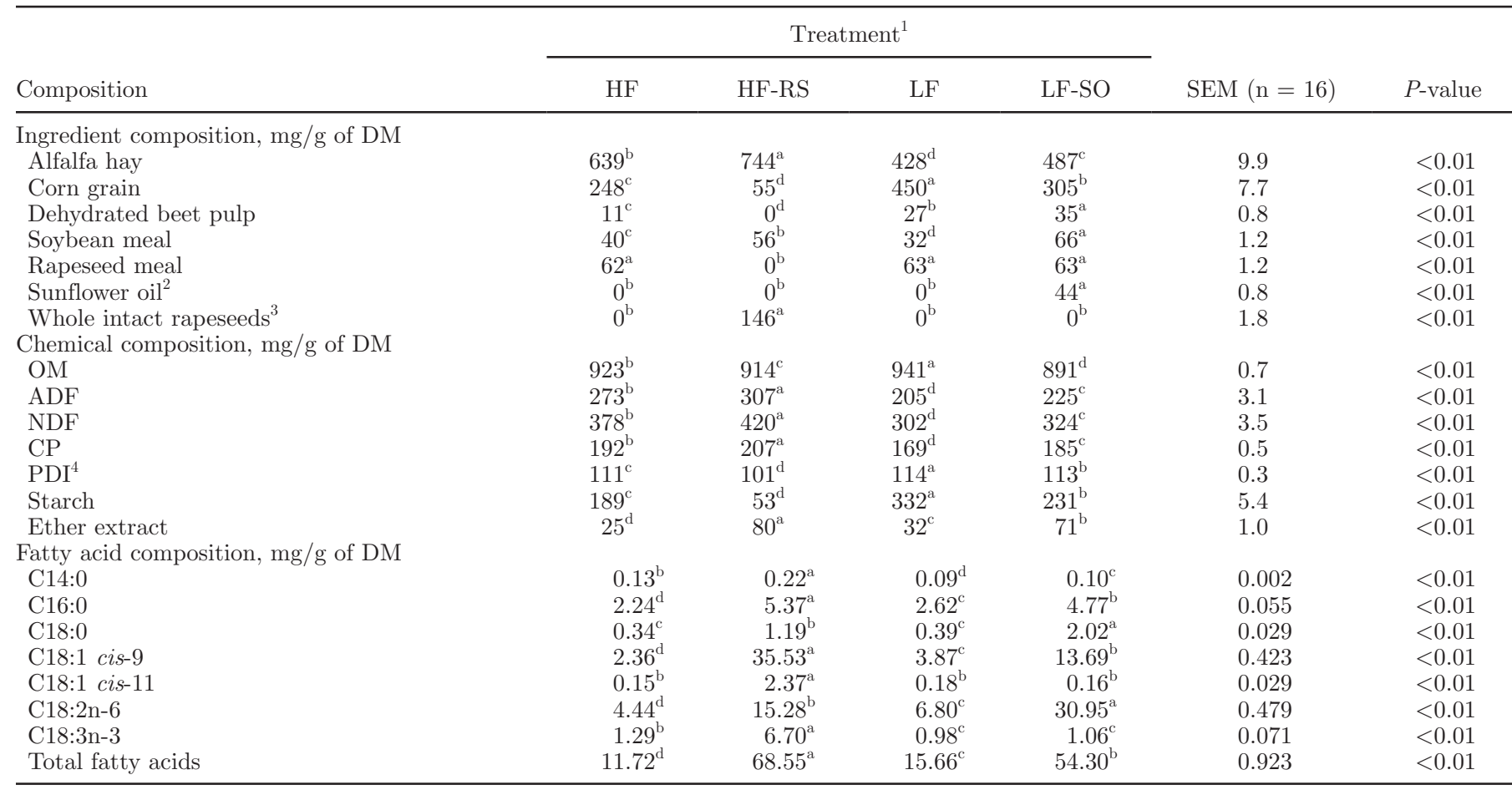

${ }^{\mathrm{a}-\mathrm{d}}$ Means within a row with different superscripts differ $(P<0.05)$.

${ }^{1}$ Treatment: HF $=$ high forage; HF-RS = high forage with whole intact rapeseeds; LF = low forage; LF-SO = low forage with sunflower oil. ${ }^{2}$ Sunflower oil contained (g/100 g of fatty acids) C16:0 (6.0), C18:0 (4.0), C18:1 cis-9 (26.1), and C18:2n-6 (61.8).

${ }^{3}$ Whole intact rapeseeds contained (g/100 g of fatty acids) C16:0 (6.0), C18:0 (1.5), C18:1 cis-9 (56.4), C18:1 cis-11 (3.8), C18:2n-6 (21.6), and C18:3n-3 (8.6).

${ }^{4} \mathrm{PDI}=$ protein digestible in the intestine.

samples were collected from each goat over 4 consecutive milkings in the last week of each experimental period (during the $2 \mathrm{~d}$ before biopsy or slaughter), stored at $4^{\circ} \mathrm{C}$, and analyzed (CILAL, Theix, France) by near-infrared spectroscopy (AOAC, 1997) for fat, true protein, and lactose contents and for milk fat lipolysis (from 2 consecutive milkings) after $26 \mathrm{~h}$ of storage at $4^{\circ} \mathrm{C}$ postmilking. Additional milk samples were also collected over 2 consecutive milkings on the day before biopsy or slaughter and were stored at $-20^{\circ} \mathrm{C}$ until determination of FA composition and LPL activity.

\section{FA Analysis}

Lipids in alfalfa hay and concentrate ingredients were extracted using a mixture of chloroform and methanol (2:1, vol/vol; Folch et al., 1957) and transesterified to FA methyl esters (Loor et al., 2005) using C23:0 (Sigma, Saint-Quentin Fallavier, France) as an internal standard.

Fatty acids from lyophilized milk were extracted, methylated, and separated as described by Chilliard et al. (2006). Hexane (2 mL, HPLC grade) was added to $130 \mathrm{mg}$ of lyophilized (Thermovac TM-20, Froilabo, Ozoir-La-Ferrière, France) milk, followed by $2 \mathrm{~mL}$ of $0.5 M$ sodium methylate. This mixture was vortexed and heated at $50^{\circ} \mathrm{C}$ for $15 \mathrm{~min}$, after which $75 \mu \mathrm{L}$ of $12 \mathrm{M} \mathrm{HCl}$ was added and allowed to react for $15 \mathrm{~min}$ at ambient temperature. Hexane $(3 \mathrm{~mL})$ and deionized water $(3 \mathrm{~mL})$ were added, and the mixture was centrifuged $\left(1,160 \times g, 5 \mathrm{~min}, 5^{\circ} \mathrm{C}\right)$. Fatty acid methyl esters were separated on a $100 \mathrm{~m} \times 0.25 \mathrm{~mm}$ i.d. fused-silica capillary column (CP-Sil 88, Chrompack, Middelburg, the Netherlands). Samples were injected (0.5 to $1 \mu \mathrm{L}$ methyl esters in hexane injected at a 50:1 split ratio) by autosampler into a Trace-GC 2000 Series gas chromatograph equipped with a flame-ionization detector (Thermo Finnigan, Les Ulis, France). The injector temperature was maintained at $255^{\circ} \mathrm{C}$ and the detector temperature was maintained at $260^{\circ} \mathrm{C}$. The initial oven temperature was held at $70^{\circ} \mathrm{C}$ for 1 min, increased by $5^{\circ} \mathrm{C} / \mathrm{min}$ increments to $100^{\circ} \mathrm{C}$ and held for $2 \mathrm{~min}$, then increased by $10^{\circ} \mathrm{C} / \mathrm{min}$ to $175^{\circ} \mathrm{C}$ and held for 40 min, and finally increased by $5^{\circ} \mathrm{C} / \mathrm{min}$ up to a final temperature of $225^{\circ} \mathrm{C}$ and held for $15 \mathrm{~min}$. Hydrogen was the carrier gas and the injector pressure was held 
at a constant $158.6 \mathrm{kPa}$. Satisfactory separations of cis and trans $\mathrm{C} 18: 1$, nonconjugated $\mathrm{C} 18: 2$, and conjugated linoleic acid (CLA) isomers were obtained with a single chromatographic run. The C18:1, C18:2, CLA, and C18:3 isomers and odd- and branched-chain FA were identified as described by Loor et al. (2005). Peaks were routinely identified by comparison of retention times with FA methyl ester standards (GLC 463, Nu-Chek Prep Inc., Elysian, MN; reference mixture 47885, Supelco, Bellefonte, PA; and a custom preparation of C18:1, C18:2, and CLA isomers as described by Loor et al., 2003, kindly donated by J. H. Herbein, Virginia Tech, Blacksburg, VA). Correction factors for C4:0 to C10:0 were determined on each day of analysis using a butter oil reference standard (CRM 164, Community Bureau of Reference, Brussels, Belgium). ChromQuest software (ChromQuest Version 3.0, Thermo-Quest Corporation, San Jose, CA) was used for peak integration.

\section{Milk LPL Activity}

Lipoprotein lipase activity was directly measured in milk by using an artificial emulsion containing $\left[{ }^{3} \mathrm{H}\right]$ triolein (Faulconnier et al., 1994). Enzyme activity was expressed as nanomoles of FA released per minute per milliliter.

\section{Mammary Tissue Sampling and RNA Isolation}

At the end of the first 3 experimental periods (on d 26 for period 1 and on d 25 for periods 2 and 3 ), approximately $20 \mathrm{mg}$ of mammary tissue was taken from the upper one-third of the posterior area of 1 half udder with a Monopty biopsy needle (Bard, Voisins-leBretonneux, France) according to the instructions of the manufacturer, alternately between udders at each period. Tissue biopsies ( 1 to 2 pieces of approximately $20 \mathrm{mg}$ /animal) were rinsed in $0.9 \%$ sterile saline solution and inspected visually to verify tissue homogeneity and were then snap-frozen in liquid nitrogen and kept at $-80^{\circ} \mathrm{C}$ until RNA extraction. The biopsy procedure resulted in minimal bleeding, and no IMI or loss of production was encountered. At the end of the last experimental period, all goats ( 8 on d 24 and 8 on d 25) were slaughtered immediately after milking to eliminate most of the milk contained in the glands. Immediately after death, approximately $50 \mathrm{~g}$ of mammary tissue from the secretory area was collected under sterile conditions. Samples were immediately frozen in liquid nitrogen and stored at $-80^{\circ} \mathrm{C}$ until RNA extraction.

Total RNA was prepared from approximately $20 \mathrm{mg}$ of mammary tissue by using the SV Total RNA Isolation system (Promega, Charbonnières, France), includ- ing a DNase treatment step to eliminate contaminating genomic DNA. Concentration and purity of RNA were determined by spectrophotometry (Lambda $25 \mathrm{UV} /$ visible spectrometer, Perkin-Elmer Instruments, Les Ulis, France) at 260, 280, and $320 \mathrm{~nm}\left(\mathrm{~A}_{260}-\mathrm{A}_{320} / \mathrm{A}_{280}\right.$ - $\mathrm{A}_{320}$, where $\mathrm{A}$ is absorbance, ranged from 1.807 to 2.072). Integrity of RNA was assessed by electrophoretic analysis of $28 \mathrm{~S}$ and $18 \mathrm{~S}$ rRNA subunits with a 2100 Bioanalyzer (Agilent Technologies, Massy, France).

\section{Quantitative Real-Time Reverse Transcription-PCR}

Reverse transcription (RT) was performed from $4 \mu \mathrm{g}$ of purified total RNA with $10 \mathrm{pmol}$ of oligo(dT) and $200 \mathrm{U}$ of Superscript II RNase $\mathrm{H}^{-}$reverse transcriptase (Invitrogen Life Technologies, Cergy-Pontoise, France) in a final volume of $20 \mu \mathrm{L}$. The reaction mix was then diluted with $30 \mu \mathrm{L}$ of sterile water. Real-time PCR was carried out with $4 \mu \mathrm{L}$ of 50 -fold-diluted (in sterile water) single-strand cDNA on a LightCycler system (Roche Molecular Biochemicals, Indianapolis, IN) using either the LightCycler FastStart DNA Master SYBR Green I kit (Roche Applied Science, Meylan, France) or the LightCycler FastStart DNA Master HybProbe kit (Roche Applied Science, Meylan, France) as described previously (Ollier et al., 2007), with 10 pmol of specific primers (Eurogentec, Seraing, Belgium; Table 2) and, if available, $10 \mathrm{pmol} / \mu \mathrm{L}$ of Taqman probe (Applied Biosystems, Warrington, UK; Table 2). Briefly, for SYBR Green technology, after an initial denaturing step $\left(95^{\circ} \mathrm{C}\right.$ for $15 \mathrm{~min}$ ), the PCR mixture was subjected to the following 3-step cycle, repeated 40 times: denaturing for $15 \mathrm{~s}$ at $94^{\circ} \mathrm{C}$, annealing for $20 \mathrm{~s}$ at 58 or $60^{\circ} \mathrm{C}$ (depending of the primer pairs), and extension for $16 \mathrm{~s}$ at $72^{\circ} \mathrm{C}$. Real-time PCR based on Taqman probe technology was performed under the following conditions: $10 \mathrm{~s}$ at $95^{\circ} \mathrm{C}$ and $20 \mathrm{~s}$ at $58^{\circ} \mathrm{C}$, repeated 40 times. For each of the $13 \mathrm{cDNA}$ amplified, RNA quantification was determined from a calibration curve obtained from 5-point serial dilutions of a recombinant plasmid containing the studied cDNA sequence. A set of reference genes is optimal for accurate real-time RT-PCR normalization (Vandesompele et al., 2002); however, this was beyond the scope of the present study. Thus, although relying on treatment effects as a guide for the selection of reference genes for normalization is not the most optimal, the lack of response of goat mammary gland cyclophilin A (PPIA) mRNA to nutritional factors in previous studies (Bernard et al., 2005a, 2009a) allowed us to use this gene as an internal standard reference gene. Results are expressed as fold change relative to HF treatment after normalization with PPIA mRNA expression. 
Table 2. Primer and probe sequences used for real-time reverse transcription-PCR

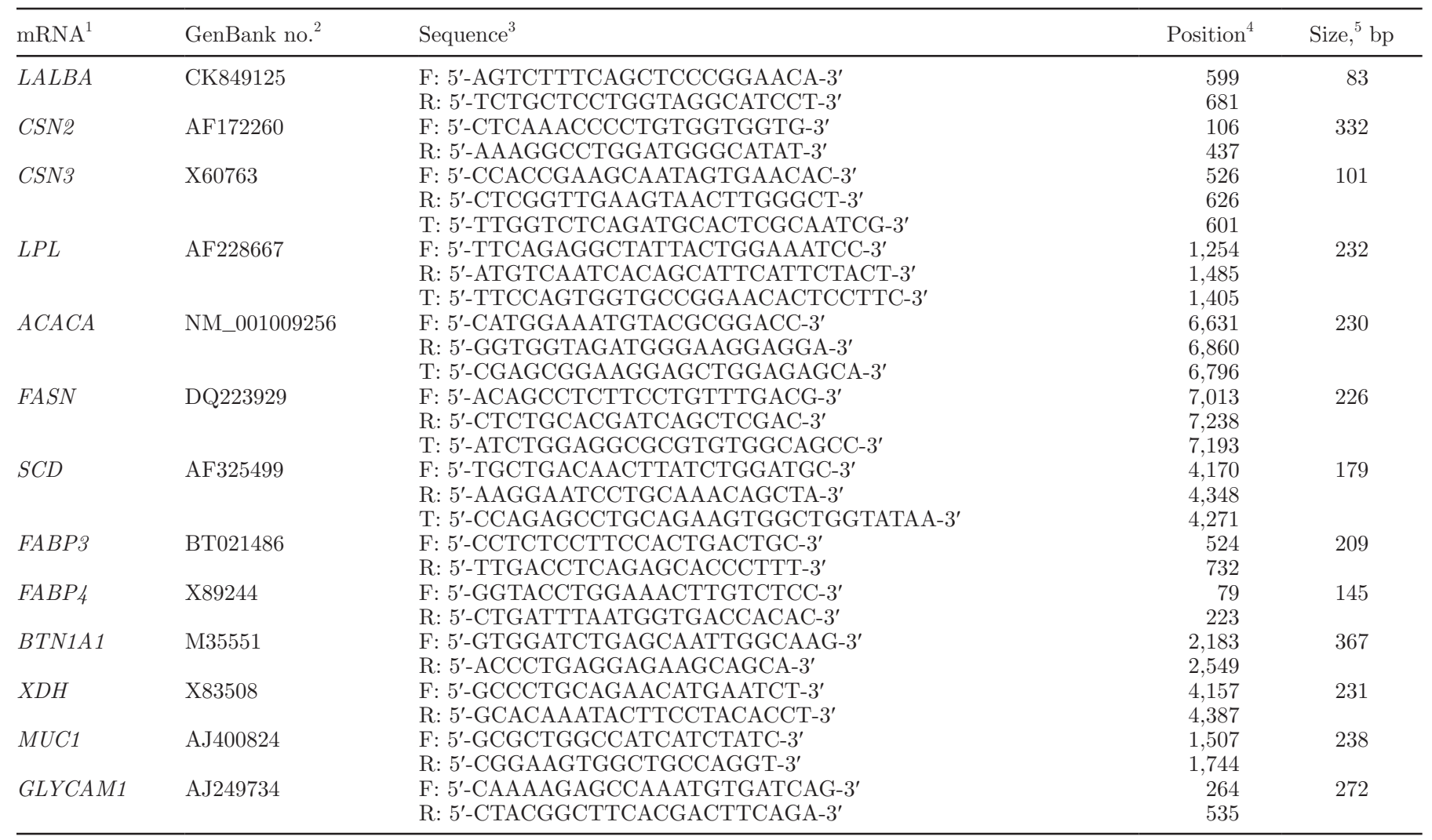

${ }^{1} \mathrm{mRNA}: L A L B A=\alpha-\mathrm{LA} ; C S N 2=\beta-\mathrm{CN} ; C S N 3=\kappa-\mathrm{CN} ; L P L=$ lipoprotein lipase $A C A C A=$ acetyl-coenzyme A carboxylase $\alpha ; F A S N=$ fatty acid synthase; $S C D=$ stearoyl-coenzyme A desaturase; $F A B P 3=$ heart-type fatty acid-binding protein; $F A B P 4=$ adipocyte-type fatty acidbinding protein; $B T N 1 A 1=$ butyrophilin; $X D H=$ xanthine dehydrogenase/oxidase; $M U C 1=$ mucin-1; GLYCAM1 = glycosylation-dependent cell adhesion molecule 1.

${ }^{2}$ Accession number of the sequence used to design primers and probes.

${ }^{3}$ Sequences: $\mathrm{F}=$ forward primer; $\mathrm{R}=$ reverse primer; $\mathrm{T}=$ Taqman probe.

${ }^{4}$ Hybridization position on the sequence.

${ }^{5}$ Amplicon size in base pairs (bp).

\section{DNA Microarrays and Data Analysis}

Because of the absence of a caprine microarray and the fact that structural genomic studies on domestic animals have shown that goats are closely related to bovine species (Schibler et al., 1998), caprine transcriptome analyses were performed using a bovine oligonucleotide microarray, as described previously by Ollier et al. (2007). We had previously compared hybridizations of lactating goat and cow mammary tissues in this bovine microarray, and results showed a correlation of 0.93 between the 2 species (unpublished results). Briefly, the microarray consisted of the Operon Bos taurus (bovine) AROS V1.1 set (Operon Biotechnologies, Cologne, France), which contains 8,329 70-mer oligonucleotides representing 8,329 unique genes from the B. taurus genome, supplemented by 53 oligonucleotides representing 53 genes chosen for their potential importance in mammary metabolism, and the Operon B. tau- rus (bovine) AROS Controls set (380 controls). These sets were spotted in duplicate on UltraGAPS Coated Slides (Corning B.V. Life Sciences, NE Schiphol-Rijk, the Netherlands) at the Biochips platform of the Génopole Toulouse Midi-Pyrénées (Toulouse, France). This platform has been registered in the National Center for Biotechnology Information Gene Expression Omnibus (GEO; http://www.ncbi.nlm.nih.gov/geo/) and is accessible through GEO Platform accession number GPL5451.

Because of the limited quantity of mammary RNA available, equal amounts $(1.25 \mu \mathrm{g})$ of total RNA sample from the mammary gland of each of the 4 goats in each treatment group were combined before labeling for each experimental period, resulting in 16 composited samples, 4 per treatment (Figure 1). Each pooled mammary sample was tested against a common standard (Figure 1) produced by mixing equal amounts of purified total RNA from several caprine tissues (lactating mam- 
mary gland, muscle, adipose tissue, heart, liver, spleen, kidney, lung, and uterus) available in our laboratory. The concentration and purity of RNA in each sample used were determined by spectrophotometry, and RNA integrity was assessed by electrophoretic analysis of $28 \mathrm{~S}$ and $18 \mathrm{~S}$ rRNA subunits with a 2100 Bioanalyzer before and after pooling $\left(\mathrm{A}_{260}-\mathrm{A}_{320} / \mathrm{A}_{280}-\mathrm{A}_{320}\right.$ was 1.813). Five micrograms of total RNA was labeled using the Pronto Plus Direct System (Promega and Corning B.V. Life Sciences). This RNA quantity is optimal when using this system (as indicated by the manufacturer), and an increase in this quantity is not accompanied by an increase in signal intensities. Fluorescently labeled cDNA from each of the 16 pooled samples (4 per dietary treatment) and fluorescently labeled cDNA from the common standard were obtained as described previously (Ollier et al., 2007). The labeling yield was controlled to be homogeneous between samples. However, to limit the variability attributable to labeling, each microarray was cohybridized, as recommended by the manufacturer, with 40 pmol of incorporated Cy3 from one pooled mammary sample and $40 \mathrm{pmol}$ of incorporated Cy5 from one reference aliquot with the Pronto Plus Direct System (Promega and Corning B.V. Life Sciences), as described previously (Ollier et al., 2007). Each hybridization was repeated in a dyeswap manner, giving a total of 32 slides $(2$ slides $\times 4$ independent pooled samples $\times 4$ dietary treatments). The slides were scanned for both dye channels at 532 and $635 \mathrm{~nm}$ with an InnoScan 700A scanner (Innopsys, Carbonne, France) at $10-\mu \mathrm{m}$ resolution. The signal and background intensity values for the $\mathrm{Cy} 3$ and $\mathrm{Cy} 5$ channels from each spot were obtained with ImaGene 6.0 software (BioDiscovery Inc., Proteigene, Saint Marcel, France). The data have been deposited in the National Center for Biotechnology Information Gene Expression Omnibus and are accessible through GEO Series accession number GSE11592.

Microarray data were preprocessed and analyzed using free R2.6 software (http://cran.r-project.org/ web/packages/anapuce/index.html). Poorly expressed and missing spots (signal mean - background mean $<3$ background SD), poor-quality spots, and saturated spots were filtered out before normalization. Hence, an average of 13,895 "good" spots per array (between 11,027 and 15,961) were used for the following analyses. After a base-2 logarithmic transformation, data were normalized by a global Lowess regression, followed by a block-effect correction via subtraction of the median by block. Between-array (dye-swap) and within-array (2 per sample) replicates were averaged (yielding an average of 6,538 genes with valid logarithmic ratios per array replicate) to increase the precision and accuracy of estimated ratios and to remove the effect of labeling.
Only genes with valid logarithmic ratios for all 32 arrays (corresponding to 16 comparisons $\times 2$ because of the dye-swap) were selected for further analysis. This stringent procedure was chosen because of the lack of a high number of replicates. This yielded 3,822 genes. Thus, the 16 logarithmic ratios between a mammary sample (4 per dietary treatment) and reference obtained were analyzed by ANOVA, including diet, period, and animal group effects. The computed residual variances were modeled by adapting the R/VarMixt package (Delmar et al., 2005; http://cran.r-project.org/web/ packages/varmixt/index.html) to detect differentially expressed genes between dietary treatments. To control the false discovery rate attributable to multiple testing, probability values were adjusted using the Benjamini-Hochberg method. Differences were considered significant at adjusted $P<0.05$. Furthermore, a 2 -way hierarchical clustering analysis was performed on the 16 mammary samples for genes whose expression was identified by ANOVA $(P<0.05)$ as being altered by diet. This clustering analysis was performed with PermutMatrix software (Caraux and Pinloche, 2005), using Pearson's distance calculation and Ward's minimum variance method for data aggregation. Genes in the same cluster were then distributed among functional categories according to their biological process ontology by using the Web-accessible DAVID (Database for Annotation, Visualization, and Integrated Discovery) program, which can identify statistically overrepresented functional categories within a given list of genes, based on a modified Fisher's exact $P$-value (Dennis et al., 2003).

\section{Statistical Analysis}

Data (except for microarray data) from the 4 experimental periods $(\mathrm{n}=64)$ were submitted to ANOVA by the GLM procedure of the SAS software package (SAS Institute Inc., Cary, NC), covering a $4 \times 4$ Latin square design replicated 4 times. The model included the effects of diet, period, and goat. When the analysis returned a significant effect attributable to dietary treatment, treatment means ( $\mathrm{n}=16$ goats) were compared using the least significant difference test in the SAS software. Significance was declared at $P<0.05$.

\section{RESULTS}

\section{Diet Composition}

The chemical and FA compositions of the ingested experimental diets are presented in Table 1 . The percentage of hay in the total DMI $(64 \%$ for the HF diet and $43 \%$ for the LF diet) was close to the values ex- 


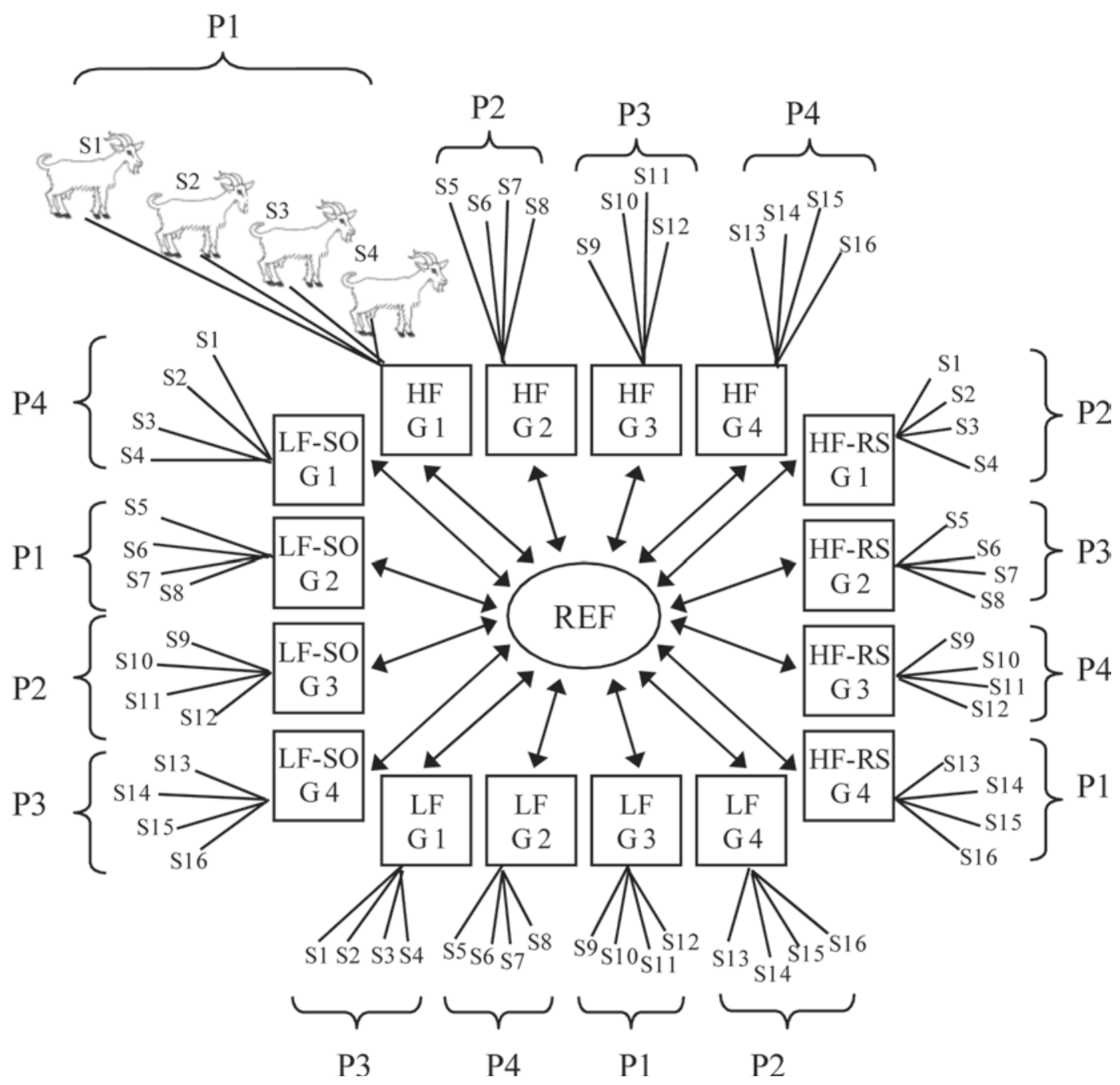

Figure 1. Experimental microarray design. Each pooled mammary sample was cohybridized with a common reference sample obtained from several caprine tissues. The 2-way arrows represent hybridizations between mammary and reference samples in a dye-swap manner. The squares represent the 4 dietary treatments (HF, HF-RS, LF, and LF-SO) and the 4 independent biological replicates (G1 to G4, corresponding to 4 groups of 4 goats) for each treatment. From each of the 4 goats receiving the same diet during the same period, $1.25 \mu \mathrm{g}$ of total RNA was mixed to produce $5 \mu \mathrm{g}$ of the total RNA of one group used for each labeling. Abbreviations used: $\mathrm{S}=$ sample from individual goat (1 to 16$)$; $\mathrm{P}$ $=$ period of the Latin square experiment (1 to 4); G1 = group of goats S1 to 4; G2 = group of goats S5 to 8; G3 = group of goats S9 to 12; G4 $=$ group of goats S13 to $16 ; \mathrm{HF}=$ high forage; HF-RS = high forage with whole intact rapeseeds; LF $=$ low forage; LF-SO = low forage with sunflower oil; REF = reference.

pected from the experimental design. The ADF and NDF were higher and starch content was lower in the HF diets than in the LF diets $(P<0.05)$. The higher content of total FA in the lipid-supplemented diets was offset by lower starch content $(P<0.05)$. The major FA provided by the HF-RS diet were cis-9 C18:1, C18:2n-6, and C18:3n-3, whereas the LF-SO diet provided mainly C18:2n-6 and cis-9 C18:1. Crude protein concentrations were higher, whereas PDI concentrations were lower in the HF diets compared with the LF diets $(P<0.05)$. Crude protein concentrations were higher, whereas PDI concentrations were lower in the lipid-supplemented diets compared with the nonsupplemented $\operatorname{diets}(P<$ $0.05)$.

\section{DMI and Milk Production and Composition}

The effects of dietary treatments on DMI, milk yield, and milk composition after 3 wk of treatment are presented in Table 3. The DMI was similar in all treatment groups $(3.06 \mathrm{~kg} / \mathrm{d}$ on average). Milk, protein, and lactose yields were lower $(P<0.05)$ with the HF-RS diet than with the other diets $(-9,-9$, and $-10 \%$ on average, respectively). There was no significant treatment effect on milk protein content. Milk lactose content was higher $(P<0.05)$ with the LF diet than with the HF diet $(+1.4 \%)$, whereas the change in forage-to-concentrate ratio had no significant effect on the other parameters studied. Lactose content was higher $(P<0.05)$ with the 
Table 3. Effect of diet on DMI, milk yield, milk composition, lipolysis, and milk lipoprotein lipase (LPL) activity in goats

\begin{tabular}{|c|c|c|c|c|c|c|}
\hline Item & \multicolumn{4}{|c|}{ Treatment $^{1}$} & SEM $(\mathrm{n}=16)$ & $P$-value \\
\hline DMI, kg/d & 3.10 & 3.17 & 2.96 & 2.99 & 0.060 & 0.06 \\
\hline \multicolumn{7}{|l|}{ Protein } \\
\hline $\mathrm{g} / \mathrm{d}$ & $135^{\mathrm{a}}$ & $123^{\mathrm{b}}$ & $134^{\mathrm{a}}$ & $138^{\mathrm{a}}$ & 2.7 & $<0.01$ \\
\hline $\mathrm{g} / \mathrm{kg}$ & 31.9 & 32.3 & 32.2 & 32.5 & 0.19 & 0.22 \\
\hline $\mathrm{g} / \mathrm{kg}$ & $45.7^{\mathrm{c}}$ & $46.4^{\mathrm{b}}$ & $46.3^{\mathrm{b}}$ & $47.8^{\mathrm{a}}$ & 0.18 & $<0.01$ \\
\hline \multicolumn{7}{|l|}{ Fat } \\
\hline $\mathrm{g} / \mathrm{d}$ & $140^{\mathrm{bc}}$ & $147^{\mathrm{b}}$ & $135^{\mathrm{c}}$ & $162^{\mathrm{a}}$ & 2.8 & $<0.01$ \\
\hline $\mathrm{g} / \mathrm{kg}$ & $32.7^{\mathrm{b}}$ & $38.7^{\mathrm{a}}$ & $32.1^{\mathrm{b}}$ & $38.2^{\mathrm{a}}$ & 0.67 & $<0.01$ \\
\hline Lipolysis $^{2}$ & $0.17^{\mathrm{a}}$ & $0.09^{\mathrm{b}}$ & $0.19^{\mathrm{a}}$ & $0.11^{\mathrm{b}}$ & 0.016 & $<0.01$ \\
\hline LPL, nmol/min per $\mathrm{mL}$ & 379 & 298 & 472 & 340 & 61.9 & 0.25 \\
\hline
\end{tabular}

${ }^{\mathrm{a}-\mathrm{c}}$ Means within a row with different superscripts differ $(P<0.05)$.

${ }^{1}$ Treatments: $\mathrm{HF}=$ high forage; HF-RS $=$ high forage with whole intact rapeseeds; LF = low forage; LF-SO = low forage with sunflower oil.

${ }^{2}$ Lipolysis: FFA expressed as grams of cis-9 C18:1/100 g of milk fat after $26 \mathrm{~h}$ of storage at $4^{\circ} \mathrm{C}$.

lipid-supplemented HF-RS and LF-SO diets than the $\mathrm{HF}$ and LF diets $(+1.6$ and $+3.2 \%$, respectively). Milk fat content was higher $(P<0.05)$ with the HF-RS and LF-SO diets than with the HF and LF diets $(+18$ and $+19 \%$, respectively). Supplementing the LF diet with SO increased $(P<0.05)$ the milk fat yield compared with no supplementation $(+20 \%)$. Milk fat lipolysis was lower $(P<0.05)$ with the HF-RS and LF-SO diets compared with the HF and LF diets $(-47$ and $-42 \%$, respectively), whereas lipid supplementation had no significant effect on milk LPL activity (Table 3 ).

\section{Milk FA Composition}

The effects of dietary treatments on milk FA composition are presented in Tables 4 and 5 . After 3 wk of treatment, there was a diet effect on the concentrations of all FA $(P<0.01)$.

Changes in forage-to-concentrate ratio ( $\mathrm{LF}$ vs. HF diets) had no effect on concentrations of even-chain saturated short- and medium-chain FA (C4:0 to C16:0), except for C12:0 concentration, which was slightly increased $(P<0.05)$ with the LF diet $(+7 \%)$. Odd-chain saturated short- and medium-chain FA (C5:0 to C13:0) concentrations were higher $(P<0.05)$ with the LF diet than the HF diet (between $+16 \%$ for $\mathrm{C} 13: 0$ and $+50 \%$ for C9:0). Except for iso C14:0, all branched-chain FA concentrations measured were lower $(P<0.05)$ with the LF diet than with the HF diet (between $-11 \%$ for iso $\mathrm{C} 16: 0$ and $-29 \%$ for iso C18:0). Changes in forageto-concentrate ratio had no effect on C18:0 concentration or on concentrations of cis-9 C18:1 and other $\Delta^{9}$ monounsaturated FA (cis-9 C10:1, cis-9 C14:1, and cis9 C16:1). Except for cis-11 C18:1 concentration, which increased $(P<0.05)$ with the LF diet compared with the HF diet $(+18 \%)$, concentrations of milk cis C18:1 isomers did not differ between the HF and LF diets, whereas the sum of milk trans $\mathrm{C} 18: 1$ concentrations was higher $(P<0.05)$ with the LF diet than with the HF diet $(+41 \%)$. Regarding polyunsaturated C18 FA, only trans-11, cis-15 C18:2 and C18:3n-3 concentrations were modified by the change in forage-to-concentrate ratio $(-49$ and $-38 \%$, respectively, LF vs. HF; $P<0.05)$. Compared with the HF diet, the LF diet led to lower $(P$ $<0.05$ ) concentrations of the saturated (between $-12 \%$ for $\mathrm{C} 20: 0$ and $-50 \%$ for $\mathrm{C} 24: 0)$ and polyunsaturated (between $-11 \%$ for $\mathrm{C} 20: 4 \mathrm{n}-6$ and $-16 \%$ for $\mathrm{C} 20: 5 \mathrm{n}-3$ ) very long chain FA.

Compared with the HF diet, the HF-RS diet increased $(P<0.05)$ milk $\mathrm{C} 4: 0$ concentration $(+10 \%)$ and decreased $(P<0.05)$ other even-chain saturated short-chain FA ( $-5 \%$ for C6:0 and $-15 \%$ for $\mathrm{C} 8: 0)$ and medium-chain FA (C10:0 to C16:0; between $-26 \%$ for C14:0 and $-39 \%$ for C12:0) concentrations. Except for C5:0, odd-chain saturated FA (C7:0 to C17:0) concentrations were lower $(P<0.05)$ with the HF-RS diet than with the HF diet (between $-8 \%$ for $\mathrm{C} 17: 0$ and $-44 \%$ for C13:0). Similarly, except for iso C14:0 and iso C18:0, branched-chain FA concentrations were lower $(P$ $<0.05$ ) with the HF-RS diet than the HF diet (between $-8 \%$ for iso $\mathrm{C} 15: 0$ and $-18 \%$ for iso C16:0). Milk $\Delta^{9}$ monounsaturated medium-chain FA concentrations were lower $(P<0.05)$ with the HF-RS diet than the HF $\operatorname{diet}(-32 \%$ for cis-9 C10:1 and cis-9 C16:1, and $-42 \%$ for cis-9 C14:1), whereas milk concentration of trans-11 C16:1 was higher $(P<0.05)$ with the HF-RS diet compared with the HF diet $(+133 \%)$. Compared with the HF diet, the HF-RS diet led to higher $(P<0.05)$ milk 
Table 4. Effect of diet on milk fatty acid composition and content in goats

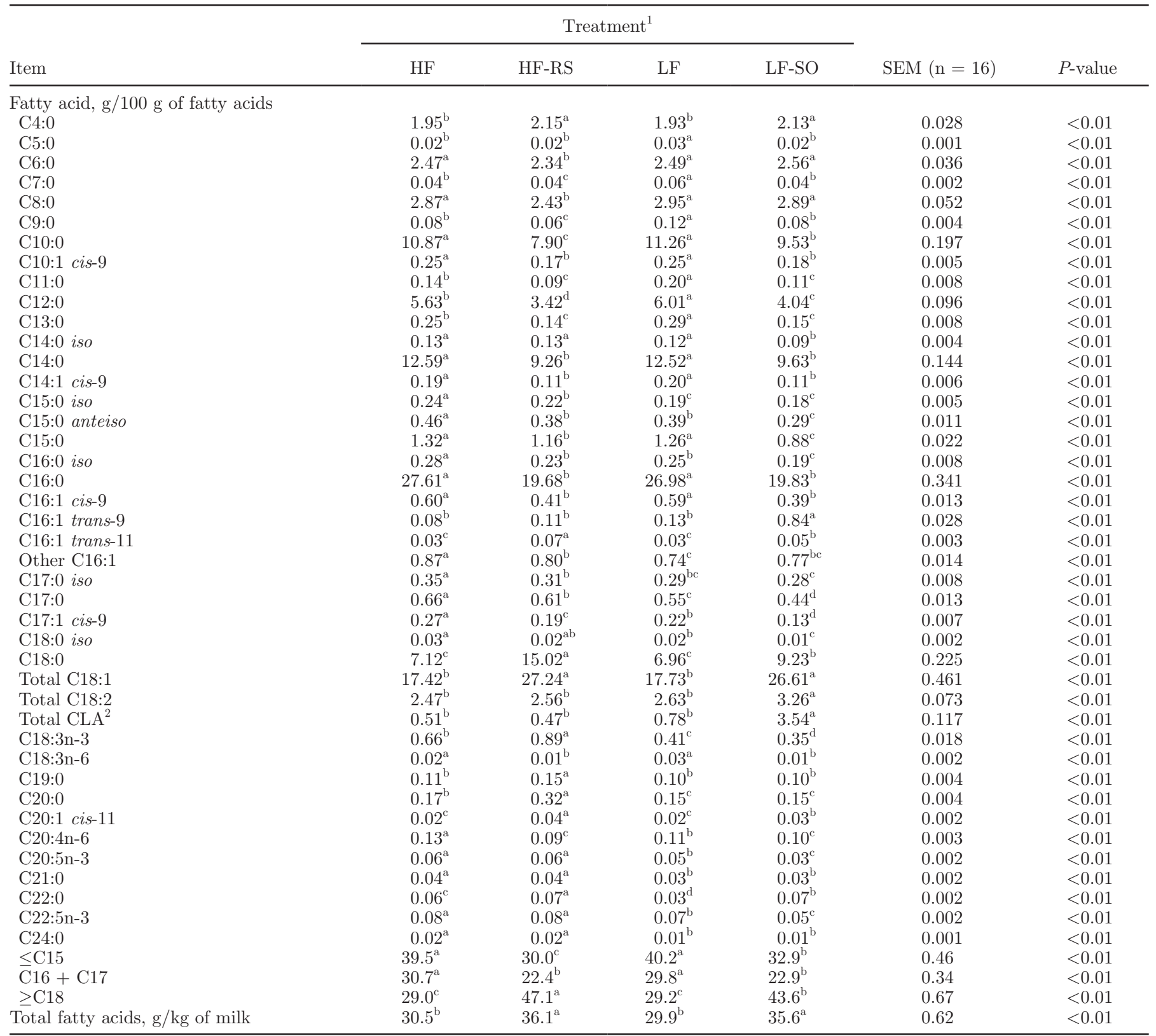

${ }^{\mathrm{a}-\mathrm{d}}$ Means within a row with different superscripts differ $(P<0.05)$.

${ }^{1}$ Treatments: $\mathrm{HF}=$ high forage; HF-RS $=$ high forage with whole intact rapeseeds; LF $=$ low forage; LF-SO $=$ low forage with sunflower oil.

${ }^{2} \mathrm{CLA}=$ conjugated linoleic acid.

C18:0 concentration $(+111 \%)$, and except for cis-11 C18:1 and trans-11 C18:1, led to higher $(P<0.05)$ concentrations of cis $(+53 \%$ in all) and trans $\mathrm{C} 18: 1$ isomers $(+84 \%)$, including increased cis-9 C18:1 $(+54 \%)$ and trans-10 C18:1 (+111\%) concentrations. Supplementation with RS had no effect on milk C18:2n-6 and cis-9, trans-11 CLA concentrations, whereas concentrations of cis-9, trans-12 C18:2, cis-9, trans-13 C18:2, trans-11, cis-15 C18:2, and C18:3n-3 were higher $(+163,+132$,
+116 , and $+35 \%$, respectively) and the concentration of C18:3n-6 was lower $(-54 \%)$ with the HF-RS diet than the HF diet $(P<0.05)$. Regarding the very long chain FA, C20:0, cis-11 C20:1, and C22:0 concentrations were higher $(+88,+132$, and $+25 \%$, respectively) and C20:4n-6 concentration was lower $(-29 \%)$ with the HF-RS diet than the HF diet $(P<0.05)$.

Compared with the LF diet, the LF-SO diet increased $(P<0.05)$ milk $\mathrm{C} 4: 0$ concentration $(+10 \%)$ but had no 
Table 5. Effect of diet on milk C18:1 and C18:2 composition in goats

\begin{tabular}{|c|c|c|c|c|c|c|}
\hline Fatty acid, $\mathrm{g} / 100 \mathrm{~g}$ of fatty acids & \multicolumn{4}{|c|}{ Treatment $^{1}$} & $\operatorname{SEM}(\mathrm{n}=16)$ & $P$-value \\
\hline C18:1 cis-9 & $14.77^{\mathrm{b}}$ & $22.68^{\mathrm{a}}$ & $14.22^{\mathrm{b}}$ & $14.84^{\mathrm{b}}$ & 0.375 & $<0.01$ \\
\hline $\mathrm{C} 18: 1$ cis-12 & $0.14^{\mathrm{c}}$ & $0.20^{\mathrm{b}}$ & $0.16^{\mathrm{bc}}$ & $0.37^{\mathrm{a}}$ & 0.015 & $<0.01$ \\
\hline C18:1 cis-13 & $0.03^{\mathrm{c}}$ & $0.08^{\mathrm{a}}$ & $0.04^{\mathrm{c}}$ & $0.05^{\mathrm{b}}$ & 0.003 & $<0.01$ \\
\hline $\mathrm{C} 18: 1$ cis- $15^{2}$ & $0.05^{\mathrm{c}}$ & $0.09^{\mathrm{a}}$ & $0.05^{\mathrm{c}}$ & $0.07^{\mathrm{b}}$ & 0.003 & $<0.01$ \\
\hline $\mathrm{C} 18: 1$ trans -5 & $0.01^{\mathrm{c}}$ & $0.04^{\mathrm{a}}$ & $0.01^{\mathrm{c}}$ & $0.03^{\mathrm{b}}$ & 0.002 & $<0.01$ \\
\hline $\mathrm{C} 18: 1$ trans $-6,7,8$ & $0.13^{\mathrm{c}}$ & $0.45^{\mathrm{a}}$ & $0.19^{\mathrm{b}}$ & $0.48^{\mathrm{a}}$ & 0.015 & $<0.01$ \\
\hline $\mathrm{C} 18: 1$ trans -9 & $0.18^{\mathrm{d}}$ & $0.36^{\mathrm{b}}$ & $0.22^{\mathrm{c}}$ & $0.52^{\mathrm{a}}$ & 0.010 & $<0.01$ \\
\hline C18:1 trans -10 & $0.19^{\mathrm{d}}$ & $0.40^{\mathrm{b}}$ & $0.26^{\mathrm{c}}$ & $0.68^{\mathrm{a}}$ & 0.023 & $<0.01$ \\
\hline C18:1 trans- 11 & $0.86^{\mathrm{b}}$ & $0.94^{\mathrm{b}}$ & $1.34^{\mathrm{b}}$ & $7.67^{\mathrm{a}}$ & 0.232 & $<0.01$ \\
\hline C18:1 trans -12 & $0.16^{\mathrm{c}}$ & $0.42^{\mathrm{a}}$ & $0.21^{\mathrm{b}}$ & $0.46^{\mathrm{a}}$ & 0.015 & $<0.01$ \\
\hline C18:1 trans- 13 & $0.31^{\mathrm{b}}$ & $0.72^{\mathrm{a}}$ & $0.36^{\mathrm{b}}$ & $0.66^{\mathrm{a}}$ & 0.024 & $<0.01$ \\
\hline $\mathrm{C} 18: 2$ cis-9, cis-12 & $2.14^{\mathrm{bc}}$ & $1.97^{\mathrm{c}}$ & $2.28^{\mathrm{b}}$ & $2.81^{\mathrm{a}}$ & 0.066 & $<0.01$ \\
\hline CLA cis- 9 , trans $-11^{4}$ & $0.51^{\mathrm{b}}$ & $0.47^{\mathrm{b}}$ & $0.78^{\mathrm{b}}$ & $3.52^{\mathrm{a}}$ & 0.116 & $<0.01$ \\
\hline
\end{tabular}

${ }^{\mathrm{a}-\mathrm{d}}$ Means within a row with different superscripts differ $(P<0.05)$.

${ }^{1}$ Treatments: $\mathrm{HF}=$ high forage; HF-RS $=$ high forage with whole intact rapeseeds; LF = low forage; LF-SO = low forage with sunflower oil.

${ }^{2}$ Contains C18:1 trans- 17 as a minor component.

${ }^{3}$ Contains C18:1 cis-14 as a minor component.

${ }^{4} \mathrm{CLA}=$ conjugated linoleic acid. The peak of cis-9, trans-11 CLA determined by gas chromatography also includes the putative contribution of several other minor isomers of CLA (trans-7, cis-9; trans-8, cis-10; and trans-6, cis-8) (e.g., Roy et al., 2006). Furthermore, only traces of trans-10, cis-12 CLA were found.

effect on concentrations of other short-chain FA (C6:0 and $\mathrm{C} 8: 0)$, and it decreased $(P<0.05)$ concentrations of saturated medium-chain FA (C10:0 to C16:0; between $-15 \%$ for C10:0 and $-33 \%$ for C12:0). Odd-chain saturated FA (C5:0 to C17:0) concentrations were lower $(P$ $<0.05$ ) with the LF-SO diet than the LF diet (between $-20 \%$ for $\mathrm{C} 17: 0$ and $-48 \%$ for C13:0). Similarly, except for iso C15:0 and iso C17:0, branched-chain FA concentrations were lower $(P<0.05)$ with the LF-SO diet than the LF diet (between $-24 \%$ for iso C16:0 and $-40 \%$ for iso C18:0). Milk $\Delta^{9}$ monounsaturated medium-chain FA concentrations were lower $(P<0.05)$ with the LF-SO diet than the LF diet $(-28 \%$ for cis-9 C10:1, $-45 \%$ for cis-9 C14:1, and $-34 \%$ for cis-9 C16:1), whereas trans-11 C16:1 and especially trans-9 C16:1 increased ( +67 and $+546 \%$, respectively; $P<0.05)$. Compared with the LF diet, the LF-SO diet increased $(P<0.05)$ milk $\mathrm{C} 18: 0$ concentration $(+33 \%)$ but did not affect the cis-9 C18:1 concentration. Concentrations of trans C18:1 isomers, except for trans-16 C18:1, were higher $(P<0.05)$ with the LF-SO diet than the LF diet $(+306 \%$ in all), including a particularly strong increase in trans-11 C18:1 concentration (+472\%). Except for cis-9, trans-13 C18:2, supplementation of the LF diet with SO led to higher $(P<0.05)$ concentrations of milk
C18:2 isomers, in particular C18:2n-6 and mainly cis-9, trans-11 CLA ( +23 and $+351 \%$, respectively), whereas $\mathrm{C} 18: 3$ isomer concentrations decreased $(-15 \%$ for C18:3n-3 and $-46 \%$ for C18:3n- $6 ; P<0.05)$. Regarding very long chain $\mathrm{FA}$, concentrations of cis-11 C20:1 and $\mathrm{C} 22: 0$ were higher $(P<0.05)$ with the LF-SO diet than with the LF diet $(+39$ and $+97 \%$, respectively), whereas polyunsaturated FA were lower $(-14 \%$ for C20:4n-6, $-38 \%$ for $\mathrm{C} 20: 5 \mathrm{n}-3$, and $-29 \%$ for $\mathrm{C} 22: 5 \mathrm{n}-3$; $P<0.05)$.

\section{Milk FA Secretion}

The effects of dietary treatments on milk FA secretion are presented in Table 6 . After 3 wk of treatment, there was a diet effect on all groups of FA $(P$ $<0.01)$. Although secretion of short-chain FA (C4:0, C6:0, and C8:0) did not differ between the HF and LF treatments or between the HF and HF-RS treatments, it was higher $(P<0.05)$ with the LF-SO diet than the $\mathrm{LF}$ diet $(+22 \%)$. The secretion of medium-chain FA (C10:0, C12:0, and C14:0) and C16:0 was unaffected by changes in forage-to-concentrate ratio but was lower $(P<0.05)$ with the HF-RS diet than the HF diet $(-25 \%$ on average). The LF-SO diet slightly 
Table 6. Effect of diet on milk fatty acid secretion, efficiency of transfer of C18 fatty acids, ${ }^{1}$ and $\Delta^{9}$-desaturation ratios in goats

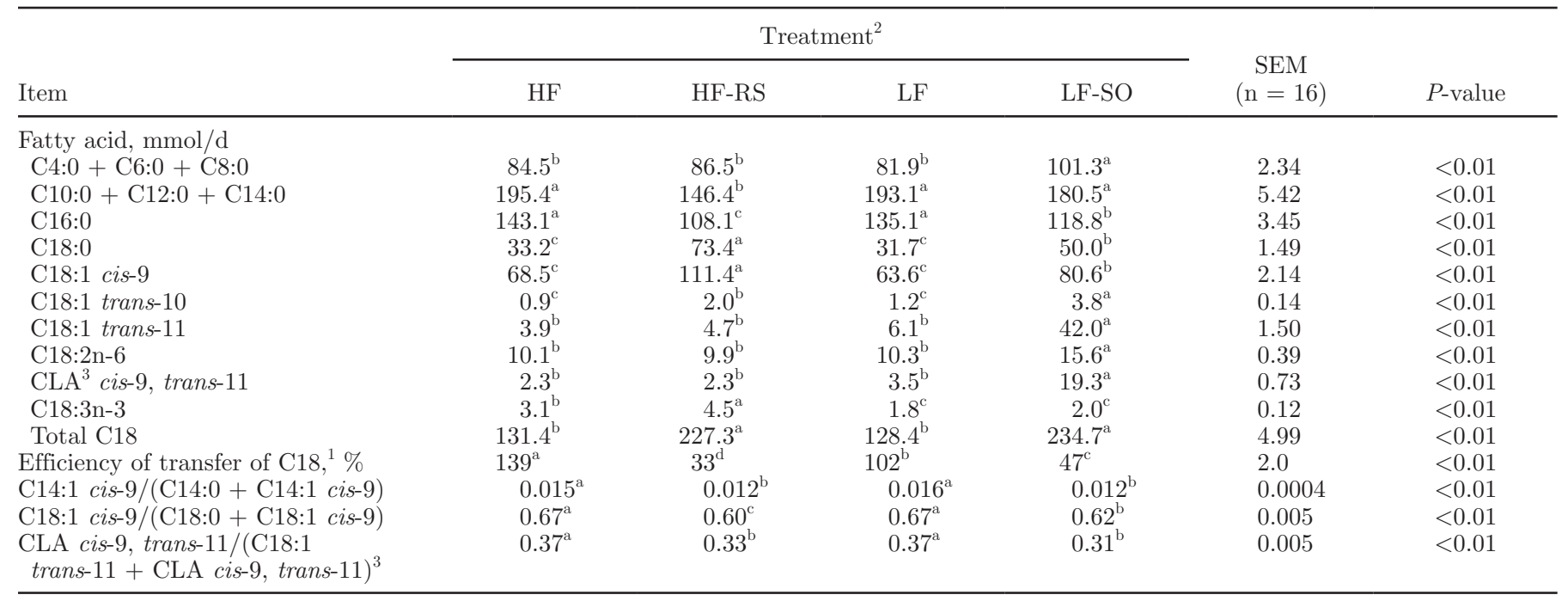

${ }^{\mathrm{a}-\mathrm{d}}$ Means within a row with different superscripts differ $(P<0.05)$.

${ }^{1}$ Efficiency of transfer of C18 fatty acids from the diet into milk was calculated as [(C18 fatty acid output in milk, g/d)/(C18 fatty acid intake, $\mathrm{g} / \mathrm{d})] \times 100$.

${ }^{2}$ Treatments: HF = high forage; HF-RS = high forage with whole intact rapeseed; LF = low forage; LF-SO = low forage with sunflower oil.

${ }^{3} \mathrm{CLA}=$ conjugated linoleic acid.

decreased $(P<0.05)$ C16:0 secretion compared with the LF diet $(-12 \%)$. The sum of C18 FA secreted in milk was higher $(P<0.05)$ with the lipid-supplemented diets HF-RS and LF-SO compared with the HF and LF diets ( +73 and $+83 \%$, respectively), whereas changes in forage-to-concentrate ratio had no effect. In particular, lipid-supplemented diets increased $(P<0.05)$ the secretion of $\mathrm{C} 18: 0$, cis-9 $\mathrm{C} 18: 1$, and trans-10 C18:1, and SO supplementation in the LF diet also increased $(P$ $<0.05$ ) the secretion of trans-11 C18:1, C18:2n-6, and cis-9, trans-11 CLA. Secretion of C18:3n-3 was higher $(P<0.05)$ with the HF-RS diet and was lower with the LF and LF-SO diets compared with the HF diet. There was also a diet effect $(P<0.01)$ on C14:0, C18:0, and trans-11 C18:1 $\Delta^{9}$-desaturation ratios, which were lower $(P<0.05)$ with the lipid-supplemented diets than with the nonsupplemented diets $(-24,-9$, and $-14 \%$ on average, respectively), whereas these ratios did not differ between the HF and LF diets. The efficiency of transfer of C18 FA from the diet into milk decreased from HF to LF to LF-SO to HF-RS (139, 102, 47, and $33 \%$, respectively; Table 6 ).

\section{Mammary mRNA Abundance of Key Genes Involved in Milk Component Metabolism}

Real-time RT-PCR was used to investigate the effect of dietary treatments on mammary expression of candidate genes associated with various major aspects of milk component synthesis and secretion (Table 7 and Supplemental Table S1; http://jds.fass.org/content/vol92/ issue11/). Diet had no significant effect on mammary mRNA abundance of $\alpha$-LA $(\boldsymbol{L} \boldsymbol{A} \boldsymbol{L} \boldsymbol{B} \boldsymbol{A})$, which encodes a major milk protein involved in lactose synthesis, and $\beta$ - and $\kappa-\mathrm{CN}$ (CSN2 and CSN3, respectively), which encode 2 other major milk proteins. Furthermore, mammary mRNA abundance of $L P L$, which is involved in FA uptake; $A C A C A$ and $F A S N$, which are involved in de novo FA synthesis; $S C D$, which is involved in FA desaturation; heart- and adipocyte-type FA-binding proteins (FABP3 and $\boldsymbol{F A B P} 4$, respectively), which are involved in FA transport; and 4 genes encoding milk fat globule membrane proteins, namely, butyrophilin (BTN1A1), xanthine dehydrogenase/oxidase $(\boldsymbol{X D H})$, mucin-1 (MUC1), and glycosylation-dependent cell adhesion molecule 1 ( $\boldsymbol{G} \boldsymbol{L} \boldsymbol{Y} \boldsymbol{C A} \boldsymbol{M} \mathbf{1})$, were not significantly changed by diet.

\section{Global Mammary Gene Expression}

To extend the study of mammary mechanisms underlying milk secretion and the composition responses to different forage-to-concentrate ratios and RS or SO supplementation, we conducted between-diet comparisons of the mammary mRNA abundance of 8,382 genes by using a bovine oligonucleotide microarray, according to the hybridization scheme shown in Figure 1. Sixteen pooled mammary samples (4 per dietary treatment) were cohybridized independently, using a common standard obtained from several caprine tissues. We opted for a reference design to allow a comparison of gene expression profiles between the 4 conditions studied. 
Table 7. Effect of diet on mammary mRNA abundance of key genes encoding enzymes involved in milk lactose, protein, and fat synthesis or secretion in goats

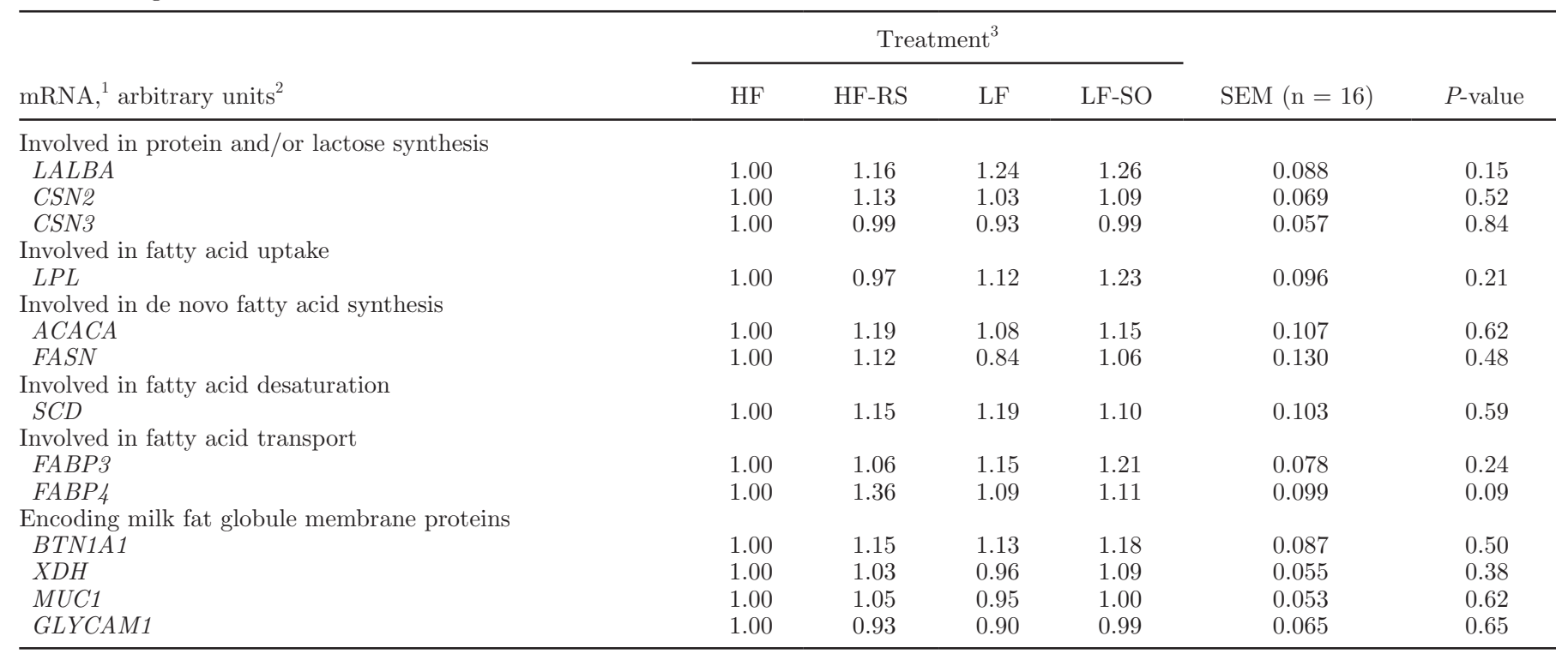

${ }^{1}$ mRNA: $L A L B A=\alpha-\mathrm{LA} ; C S N 2=\beta-\mathrm{CN} ; C S N 3=\kappa-\mathrm{CN} ; L P L=$ lipoprotein lipase $A C A C A=$ acetyl-coenzyme A carboxylase $\alpha ; F A S N=$ fatty acid synthase; $S C D=$ stearoyl-coenzyme A desaturase; $F A B P 3=$ heart-type fatty acid-binding protein; FABP $4=$ adipocyte-type fatty acidbinding protein; $B T N 1 A 1=$ butyrophilin; $X D H=$ xanthine dehydrogenase/oxidase; $M U C 1=$ mucin-1; GLYCAM1 = glycosylation-dependent cell adhesion molecule 1.

${ }^{2}$ Relative mRNA expression normalized to cyclophilin A mRNA. Expression of the HF treatment was set to 1.00.

${ }^{3}$ Treatments: HF = high forage; HF-RS = high forage with whole intact rapeseeds; LF = low forage; LF-SO = low forage with sunflower oil.

After data preprocessing, 3,822 genes were analyzed by ANOVA, revealing a diet effect $(P<0.05)$ for 196 of these genes. However, the VarMixt statistical package, which is based on a variance mixture modeling strategy (Delmar et al., 2005), was unable to detect any genes significantly differentially expressed between diets after Benjamini-Hochberg correction $(P<0.05)$ when each treatment was compared with another. However, a 2-way hierarchical clustering analysis, illustrated in Figure 2, was implemented for a set of 196 genes identified by the ANOVA model by using PermutMatrix software (Caraux and Pinloche, 2005). This unsupervised analysis allowed gene expression profiles corresponding to each dietary treatment to be separated (as indicated by arrow 1 in Figure 2). Moreover, a second level of clustering divided the samples into 2 groups (as indicated by arrow 2 in Figure 2) differing by whether the diet was supplemented with lipid: LF and HF samples were on one side and the lipid-supplemented diets LF$\mathrm{SO}$ and HF-RS were on the other. Furthermore, this classification allowed 7 clusters of genes to be defined that exhibited similar behavior based on the global expression profile, as indicated by arrow 3 in Figure 2 (see Supplemental Table S2; http://jds.fass.org/content/ vol92/issue11/). For example, cluster I mostly contained genes downregulated in HF-RS samples compared with HF samples, whereas cluster IV mostly contained genes upregulated in HF-RS samples compared with $\mathrm{HF}$ samples. Genes belonging to the same cluster were then classified among functional categories according to their biological process ontology by using the Web-accessible DAVID program, which can identify statistically overrepresented functional categories within a given list of genes (Dennis et al., 2003). This exploratory analysis revealed that different biological processes were represented in each cluster. In particular, cluster I, cluster II (which mostly contained genes downregulated in HFRS samples compared with LF), and cluster VII (which mostly contained genes downregulated in LF samples compared with LF-SO and HF-RS) were specifically rich in genes involved in the regulation of transferase activity $(P=0.006)$, amino sugar metabolism $(P=$ $0.038)$, and developmental processes $(P=0.009)$, respectively, compared with other functional categories. Three biological processes, namely, RNA splicing $(P$ $=0.007)$, protein transport $(P=0.029)$, and amine metabolism $(P=0.042)$, were specifically represented in cluster IV, whereas the clusters III, V, and VI were not significantly enriched in any particular process.

\section{DISCUSSION}

\section{Milk Production and Composition}

Decreasing the forage-to-concentrate ratio from 64:36 to $43: 57$ had a limited effect on goat milk yield 


Min $=-1.13 \quad 0.00 \quad$ Max $=1.13$
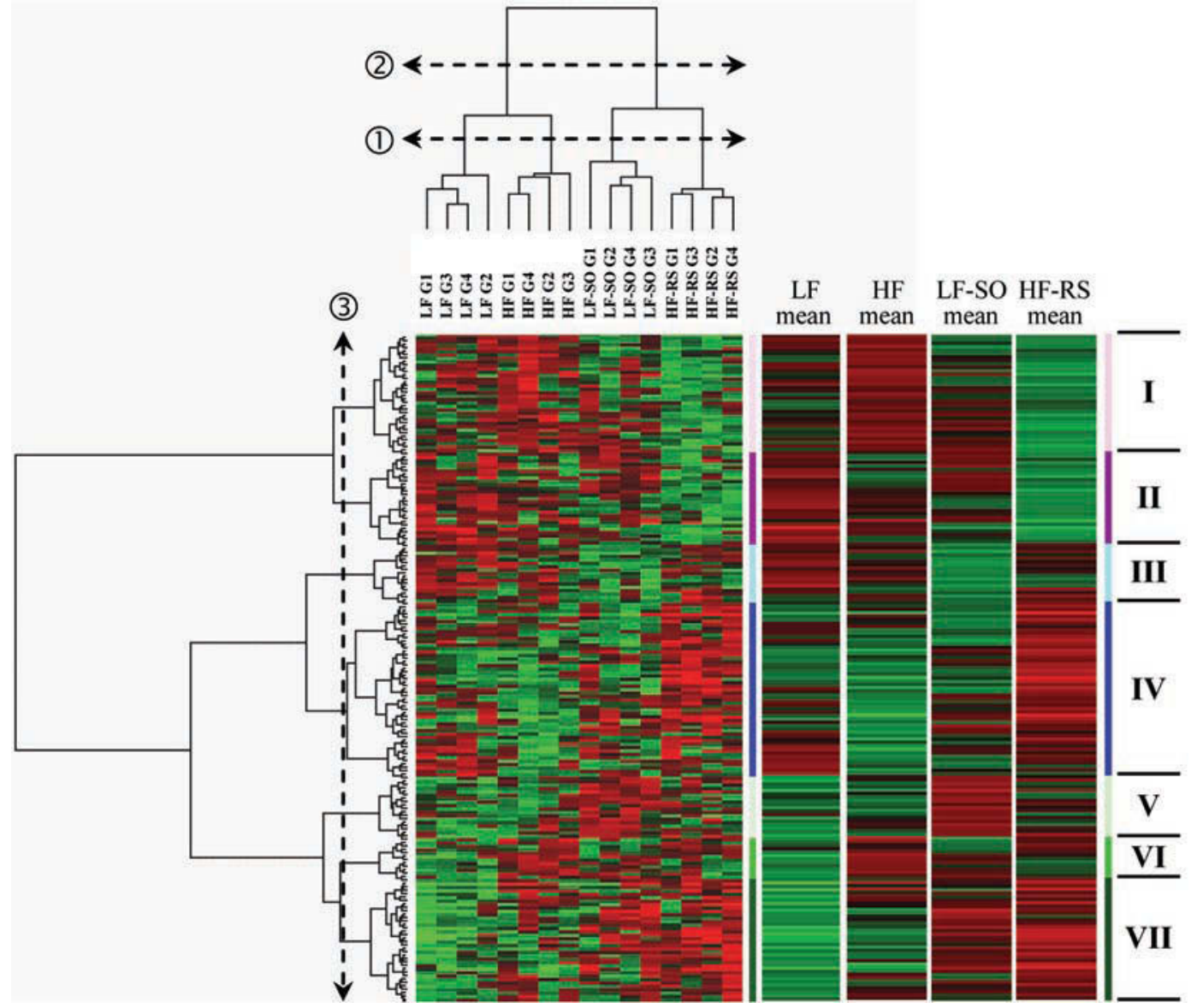

Figure 2. Two-way hierarchical clustering dendrogram of the 16 mammary samples by reference logarithmic ratios and the 196 genes with a diet effect $(P<0.05)$, performed with PermutMatrix software (Caraux and Pinloche, 2005) using Pearson's distance calculation and Ward's minimum variance method. In the left panel, columns represent each mammary sample by reference logarithmic ratio, specified by dietary treatment (HF, HF-RS, LF, and LF-SO) and biological replicate number (G1 to G4), and rows represent genes. The graphical representation is based on row-centered data. In the right panel, logarithmic ratios were averaged within the same treatment for each gene. The color scale is indicated, with red representing upregulation and green representing downregulation compared with other samples. The arrows annotated 1 and 2 divide the samples into 4 and 2 groups, respectively, and the arrow annotated 3 separates the 196 genes (listed in Supplemental Table S2; http://jds. fass.org/content/vol92/issue11/) into 7 clusters (I to VII). Abbreviations used: G1 = group of goats 1 to 4; G2 = group of goats 5 to 8; G3 = group of goats 9 to 12; G4 = group of goats 13 to 16 ; HF = high forage; HF-RS = high forage with whole intact rapeseeds; LF $=$ low forage; LF-SO = low forage with sunflower oil; $\min =$ minimum; $\max =$ maximum.

and composition, in agreement with a previous study comparing forage-to-concentrate ratios decreasing from 67:33 to 33:67 (Chilliard et al., 2007). In the present study, feeding $15 \%$ of diet DM as whole intact rapeseeds decreased milk yield without any decrease in DMI, whereas Andrade and Schmidely (2006) reported that feeding goats with 4 to $8 \%$ of diet DM as rolled rapeseeds had no effect. The negative effect of RS feeding on milk yield observed in the present study was likely not due to the lower PDI content of the diet (Table 1) because PDI balance was largely positive in all treatment groups (results not shown), but it could have been due to a decrease in diet digestibility. However, published results on direct comparisons between ground and intact rapeseeds in dairy cow feed have given contrasting results, ranging from no difference in DMI and milk yield (Kennelly, 1996) to a decrease in milk yield when feeding intact rapeseeds (Bayourthe et al., 2000), whereas Murphy et al. (1990) reported that both forms of rapeseeds led to a similar decrease in diet digestibility compared with a control diet. Even though the variety of rapeseeds used in the study by Murphy et al. (1990) was not reported, it is possible that the lack of difference (in digestibility) between ground and 
whole intact rapeseeds was due, at least in part, to the relatively high glucosinolate content in rapeseed varieties used in the 1980s compared with the rapeseeds currently available, and this may have masked putative, slight differences between the 2 forms. The higher milk fat content without a change in milk fat yield when goats were fed $15 \%$ of DM as whole intact rapeseeds could have been due to a concentration effect linked to the decrease in milk yield (Table 3). However, feeding $8 \%$ of DM as rolled rapeseeds added to a low-forage diet increased goat milk fat content and yield, whereas $4 \%$ of $\mathrm{DM}$ as rolled rapeseeds added to a high-forage diet had no effect (Andrade and Schmidely, 2006). In the present study, the decrease in milk yield with the HFRS diet could also have been due to the starch content of the diet, which was lower than reported previously (Andrade and Schmidely, 2006), and this could have limited the availability of glucose precursors for lactose synthesis in the mammary gland.

The effects of adding SO to the LF diet are in agreement with previous results on the effects of SO supplementation to concentrate-, hay-, or corn silagebased diets on goat milk content of protein (no change), fat (increase or no change), and lactose (increase) (Chilliard et al., 2003, 2007; Bernard et al., 2009b). This contrasts markedly with responses in cows receiving high-concentrate or corn silage-based diets, where SO supplementation increased milk protein content and sharply decreased milk fat content, without changing lactose content (Roy et al., 2006).

The increase in milk lactose content in goats receiving starch-enriched diets (Chilliard et al., 2003, and the present study, LF vs. HF) differs from the response in cows (e.g., Roy et al., 2006) and could have resulted from a higher digestive availability of glucose or its precursors, such as propionate, whereas the lactose response to lipid supplementation (HF-RS vs. HF, and LH-SO vs. LF) could have resulted from a glucose-sparing effect in body tissues of the higher availability of long-chain FA. Lipid supplementation markedly decreases goat milk lipolysis during postmilking storage, and this has been related to lower milk LPL activity (see Chilliard et al., 2003, for a review). In the present study, milk lipolysis decreased sharply, whereas milk LPL activity tended to decrease without reaching statistical significance because of large individual variations in LPL activity (Table 3).

\section{Milk FA Composition and Efficiency of Transfer of C18 FA}

Decreasing the forage-to-concentrate ratio from 64:36 to 43:57 had a limited effect on goat milk FA concentrations and decreased the saturated FA less markedly compared with the larger decrease in forageto-concentrate ratio from 67:33 to 33:67 reported previously (Chilliard et al., 2007). Supplementing the LF diet with SO changed almost all the FA concentrations, with decreases in medium-chain saturated and monounsaturated FA and odd-chain FA, large increases in trans C18:1 and C18:2 isomers (particularly trans-11 C18:1 and cis-9, trans-11 CLA), and a limited change (compared with changes in trans FA) in C18:0, and without a change in cis-9 C18:1. These results are in agreement with previous goat studies adding SO to lowforage, high-concentrate diets (Chilliard et al., 2003, 2007) and are probably due to well-known changes in the pathways involved in rumen biohydrogenation of dietary C18:2n-6 (Chilliard et al., 2007).

The effects of supplementing the HF diet with RS differed largely from the effects of supplementing the LF diet with SO. In particular, addition of RS decreased short- and medium-chain saturated and monounsaturated FA and markedly increased C18:0 and cis-9 C18:1, without important changes in trans $\mathrm{C} 18: 1$ and CLA. Adding 4 to $8 \%$ of rolled rapeseeds to the goat diet (Andrade and Schmidely, 2006) had less marked effects on medium-chain saturated FA, C18:0, and cis-9 $\mathrm{C} 18: 1$, but resulted in a greater increase in trans $\mathrm{C} 18: 1$, particularly trans-11 C18:1, and in CLA than in the present study.

These differences in response were likely partly due to the higher dose of rapeseeds in the present study, and partly due to the lipids in intact rapeseeds (rich in cis-9 $\mathrm{C} 18: 1$ and $\mathrm{C} 18: 2 \mathrm{n}-6$ ) being released into the rumen less rapidly than the lipids in rolled rapeseeds. Indeed, the lipid release from rolled rapeseeds probably resulted in inhibiting, to some extent, the complete biohydrogenation of dietary unsaturated FA. This would increase ruminal production of trans-11 C18:1, as previously suggested when comparing the effects of whole intact oilseeds versus free oils on goat milk C18:0 and trans-11 C18:1 concentrations (Chilliard et al., 2003). Thus, feeding whole intact rapeseeds very rich in cis-9 C18:1, which was probably almost totally hydrogenated in the rumen, resulted in a strong increase in milk C18:0 and its mammary $\Delta^{9}$-desaturation product, cis-9 C18:1. The aims of the experimental protocol were thus achieved, with one lipid supplementation mainly increasing milk trans $\mathrm{C} 18: 1$ and the other lipid supplementation mainly increasing $\mathrm{C} 18: 0$ and cis-9 C18:1.

The efficiency of transfer of C18 FA from the diet into milk was lower with the lipid-supplemented diets (Table 6), showing that a higher intake of long-chain FA (total C18 FA) results in a lower efficiency of transfer into milk, as observed in dairy cows for polyunsaturated FA infused into the duodenum (Chilliard et al., 2000). This is probably due to the higher utilization of 
C18 FA by nonmammary tissues when the availability of these FA increases, together with a high level of incorporation into phospholipids and cholesterol esters. Moreover, the efficiency of transfer of C18 FA with the HF diet was greater than 100\%, suggesting that part of these FA secreted into milk come either from synthesis by rumen microbes or from endogenous synthesis and release by peripheral tissues, particularly adipose tissues (Chilliard, 1993). The lower efficiency of C18 FA transfer observed with the HF-RS diet, compared with the LF-SO diet, was probably due to the low digestibility of whole intact rapeseeds, as reported in cows (Murphy et al., 1990). However, it is likely that digestion, intestinal absorption, and mammary uptake were sufficient to allow a large increase in the secretion of milk $\mathrm{C} 18$ in goats receiving the HF-RS diet compared with the HF diet (+73\%; Table 6$)$. The lower efficiency of C18 FA transfer observed with the LF diet, compared with the HF diet, could be due to either a greater use of absorbed FA or less release of stored FA by adipose tissue with the starch-rich diet (LF), which could either stimulate adipose lipogenesis or decrease lipolysis (Chilliard, 1993; Harvatine et al., 2009). However, we did not observe any differences in BW changes among the 4 dietary groups (data not shown).

\section{Milk Component Synthesis and Secretion}

To clarify whether the regulation level of the decrease in milk protein and lactose yields observed with the HF-RS diet was pretranslational, we conducted between-diet comparisons of mRNA content of the CSN2, CSN3, and $L A L B A$ genes encoding 3 of the 6 major proteins, representing $95 \%$ of the proteins contained in ruminant milk (see Martin et al., 2002, for a review). Moreover, $L A L B A$ is involved in lactose synthesis. The absence of a significant effect of dietary treatments, in particular the HF-RS diet, on these mRNA contents suggests that other factors, such as less substrate availability for mammary metabolism, had induced the protein and lactose yield decreases observed in this study. Another possibility is that the abundance and activity of enzymes involved in milk protein and lactose synthesis are regulated at a level other than transcription. Choi et al. (2004) has shown that the rate of milk protein mRNA translation is hormonally regulated and that this translation is upregulated by insulin plus prolactin. Moreover, Bevilacqua et al. (2006) pointed out the translational regulation of milk protein mRNA in a study showing a very low translation efficiency of CSN3, suggesting great potential for translational regulation. Further investigations including studies on the kinetics of adaptation to dietary treatments, the use of a set of reference genes for real-time RT-PCR, and mammary proteomic analyses could provide further insight into the nutritional regulation of milk constituent synthesis.

Similarly, to decipher the mechanisms involved in the increase in milk fat yield observed with the LF-SO diet and the increase in milk fat content with both lipid-supplemented diets, we studied the expression of key genes involved in lipid metabolism. Short- and medium-chain FA and approximately one-half of the C16:0 result from de novo synthesis in the mammary gland involving the 2 key enzymes ACACA and FASN, whereas long-chain FA and the other one-half of C16:0 are imported from plasma, notably through the action of LPL. In the present study, there were no changes in mRNA levels of $A C A C A, F A S N$, and $L P L$ with the RSor SO-supplemented diet compared with the nonsupplemented diets, despite a decrease in milk medium-chain FA and C16:0 secretions and an increase in milk C18 FA secretions, as are typically observed in goats fed lipid-supplemented diets (Chilliard et al., 2007; Bernard et al., 2009b). Similarly, RS or SO supplementation had no effect on the transcript levels of FABP 3 and FABP4, which encode proteins involved in FA transport. Moreover, $\Delta^{9}$-desaturation ratios, such as the cis-9 C14:1/ (C14:0 + cis-9 C14:1) ratio, which give an estimate of in vivo mammary $\Delta^{9}$-desaturation (Bernard et al., 2008), decreased because of the intake of dietary lipid supplements, without any change in mammary $S C D$ mRNA levels. In addition, RS or SO supplementation had no effect on the transcript levels encoding the 2 major milk fat globule proteins BTN1A1 and XDH, which intervene in milk fat secretion, or on 2 other milk fat globule proteins, MUC1 and GLYCAM1. Taken together, these results suggest that the mechanisms by which RS or $\mathrm{SO}$ in the diet alter milk fat composition and secretion do not involve transcriptional regulation of the candidate genes studied in this experiment corresponding to a Latin square design with $1 \mathrm{wk}$ of adaptation and 3 wk of treatment. These mechanisms could involve translational or posttranslational regulation affecting enzyme quantity or activity, respectively, as shown in rodents for ACACA, whose activation is regulated via phosphorylation-dephosphorylation mechanisms (see Kim, 1997, for a review).

These results suggest that the expression of these candidate genes was not a limiting factor but that other steps or metabolic pathways could be involved in the observed changes in milk composition and secretion, which may involve a large number of biochemical processes and therefore a large number of genes. These genes can now be investigated thanks to the recent development of ruminant microarray tools, making it possible to study nutritional effects on the mammary transcriptome, including transcripts putatively involved 
in milk component synthesis and secretion (Ollier et al., 2007). The transcriptome analyses described here made it possible to estimate the expression profile of 3,822 genes in the mammary tissue. Intertreatment comparisons were unable to identify significantly differentially expressed genes. This result is in accordance with the analysis of candidate genes described above (Table 7) as well as with previous experiments in lactating goats (Bernard et al., 2005a,b, 2008, 2009a) showing that diet had little or no effect on mammary lipogenic gene expression despite changes in milk composition and secretion. This contrasts with experiments in dairy cows showing that diets causing MFD alter mammary gene expression, particularly of genes involved in lipogenesis (Piperova et al., 2000; Ahnadi et al., 2002; Harvatine and Bauman, 2006). However, in our experiment, 2-way hierarchical clustering analysis, which is designed to find genes with similar behaviors (i.e., expression profiles), highlighted different global expression profiles between diets, showing that the 4 diets (after 3 wk of diet distribution) were discriminated by a set of 196 genes and not by significant effects on certain major individual genes. Moreover, this classification divided the samples into 2 groups according to whether lipids were added to the diet. Thus, the level of separation of the lipidsupplemented diets in the clustering was higher (level 2 in Figure 2) than the level of separation according to forage-to-concentrate ratio (level 1 in Figure 2). This allowed us to suggest that RS or SO supplementation had a larger effect on global mammary gene expression than the change in forage-to-concentrate ratio studied in the present trial, as was also observed for milk composition and secretion. Furthermore, although this exploratory analysis based on global expression profile did not highlight groups of genes involved in metabolism of lipids or other milk components, it did highlight other biological processes modified after $3 \mathrm{wk}$ of dietary treatments, which could open up new fields of investigation. Among these miscellaneous biological processes, the functional category of RNA splicing was particularly affected by RS supplementation of the HF diet. This warrants further investigation, given the important role of RNA splicing in regulating the synthesis of certain lipogenic enzymes such as ACACA and FASN (Bernard et al., 2008), as well as in milk protein synthesis (Martin et al., 2003). Indeed, alternative splicing events have been described for $\mathrm{CN}$ loci, thus providing another level of gene expression regulation in addition to transcriptional and translational regulations.

\section{CONCLUSIONS}

Supplementation of goat diets with both RS and SO strongly decreased the secretion of milk medium- chain saturated FA. The HF diet plus whole intact RS strongly increased cis-9 C18:1, whereas the LF diet plus SO strongly increased milk trans-11 C18:1 and cis-9, trans-11 CLA. Despite these changes, the dietary treatments had no effect on mammary mRNA abundance of key genes involved in milk component synthesis and, more particularly, in lipid metabolism. However, transcriptome analyses showed that the 4 diets were discriminated by groups of genes. These results are in accordance with previous results showing that feeding plant oils to dairy goats does not induce MFD and has no major effect on mammary gene expression, in contrast to their effects in dairy cows. This suggests that other factors, such as substrate availability for mammary metabolism, could play a predominant role in the response of goat milk FA secretion.

\section{ACKNOWLEDGMENTS}

We thank A. Combeau and his team for management of the animals, P. Gaydier for animal surgery, and R. Jailler and his team for slaughtering the animals. We also thank S. Bes, M. Goutte, S. Chauvet, C. Veltri, P. Capitan, C. Labonne, and D. Bany for their technical assistance in laboratory measurements, and M. Bonnet for the reference tissues. This work was supported by the LIPGENE EU-FP6 project (contract no. FOODCT-2003-505944).

\section{REFERENCES}

Ahnadi, C. E., N. Beswick, L. Delbecchi, J. J. Kennelly, and P. Lacasse. 2002. Addition of fish oil to diets for dairy cows. II. Effects on milk fat and gene expression of mammary lipogenic enzymes. J. Dairy Res. 69:521-531.

Andrade, P. V. D., and P. Schmidely. 2006. Influence of percentage of concentrate in combination with rolled canola seeds on performance, rumen fermentation and milk fatty acid composition in dairy goats. Livest. Sci. 104:77-90.

AOAC. 1997. Official Methods of Analysis. 16th ed. Assoc. Off. Anal. Chem., Gaithersburg, MD.

Bayourthe, C., F. Enjalbert, and R. Moncoulon. 2000. Effects of different forms of canola oil fatty acids plus canola meal on milk composition and physical properties of butter. J. Dairy Sci. 83:690-696.

Bernard, L., C. Leroux, M. Bonnet, J. Rouel, P. Martin, and Y. Chilliard. 2005a. Expression and nutritional regulation of lipogenic genes in mammary gland and adipose tissues of lactating goats. J. Dairy Res. 72:250-255.

Bernard, L., C. Leroux, and Y. Chilliard. 2008. Expression and nutritional regulation of lipogenic genes in the ruminant lactating mammary gland. Adv. Exp. Med. Biol. 606:67-108.

Bernard, L., C. Leroux, Y. Faulconnier, D. Durand, K. J. Shingfield, and Y. Chilliard. 2009a. Effect of sunflower-seed oil or linseed oil on milk fatty acid secretion and lipogenic gene expression in goats fed hay-based diets. J. Dairy Res. 76:241-248.

Bernard, L., J. Rouel, C. Leroux, A. Ferlay, Y. Faulconnier, P. Legrand, and Y. Chilliard. 2005b. Mammary lipid metabolism and milk fatty acid secretion in alpine goats fed vegetable lipids. J. Dairy Sci. 88:1478-1489.

Bernard, L., K. J. Shingfield, J. Rouel, A. Ferlay, and Y. Chilliard. 2009b. Effect of plant oils in the diet on performance and milk 
fatty acid composition in goats fed diets based on grass hay or maize silage. Br. J. Nutr. 101:213-224.

Bevilacqua, C., J. C. Helbling, G. Miranda, and P. Martin. 2006. Translational efficiency of casein transcripts in the mammary tissue of lactating ruminants. Reprod. Nutr. Dev. 46:567-578.

Caraux, G., and S. Pinloche. 2005. PermutMatrix: A graphical environment to arrange gene expression profiles in optimal linear order. Bioinformatics 21:1280-1281.

Chilliard, Y. 1993. Dietary fat and adipose tissue metabolism in ruminants, pigs, and rodents: A review. J. Dairy Sci. 76:38973927.

Chilliard, Y., A. Ferlay, R. M. Mansbridge, and M. Doreau. 2000. Ruminant milk fat plasticity: Nutritional control of saturated, polyunsaturated, trans and conjugated fatty acids. Ann. Zootech. 49:181-205.

Chilliard, Y., A. Ferlay, J. Rouel, and G. Lamberet. 2003. A review of nutritional and physiological factors affecting goat milk lipid synthesis and lipolysis. J. Dairy Sci. 86:1751-1770.

Chilliard, Y., F. Glasser, A. Ferlay, L. Bernard, J. Rouel, and M. Doreau. 2007. Diet, rumen biohydrogenation and nutritional quality of cow and goat milk fat. Eur. J. Lipid Sci. Technol. 109:828-855.

Chilliard, Y., J. Rouel, and C. Leroux. 2006. Goat's alpha-s1 casein genotype influences its milk fatty acid composition and delta-9 desaturation ratios. Anim. Feed Sci. Technol. 131:474-487.

Choi, K. M., I. Barash, and R. E. Rhoads. 2004. Insulin and prolactin synergistically stimulate beta-casein messenger ribonucleic acid translation by cytoplasmic polyadenylation. Mol. Endocrinol. 18:1670-1686.

Delmar, P., S. Robin, and J. J. Daudin. 2005. VarMixt: Efficient variance modelling for the differential analysis of replicated gene expression data. Bioinformatics 21:502-508.

Dennis, G. Jr., B. T. Sherman, D. A. Hosack, J. Yang, W. Gao, H. C. Lane, and R. A. Lempicki. 2003. DAVID: Database for Annotation, Visualization, and Integrated Discovery. Genome Biol. 4:R60.1-R60.11.

Faulconnier, Y., M. Thevenet, J. Flechet, and Y. Chilliard. 1994. Lipoprotein lipase and metabolic activities in incubated bovine adipose tissue explants: Effects of insulin, dexamethasone, and fetal bovine serum. J. Anim. Sci. 72:184-191.

Folch, J., M. Lees, and G. H. Sloane Stanley. 1957. A simple method for the isolation and purification of total lipids from animal tissues. J. Biol. Chem. 226:497-509.

Grosclaude, F., P. Martin, G. Ricordeau, F. Remeuf, L. Vassal, and J. Bouillon. 1994. Du gène au fromage: Le polymorphisme de la caséine alpha s1 caprine, ses effets, son évolution. INRA Prod. Anim. 7:3-19.

Harvatine, K. J., and D. E. Bauman. 2006. SREBP1 and thyroid hormone responsive spot 14 (S14) are involved in the regulation of bovine mammary lipid synthesis during diet-induced milk fat depression and treatment with CLA. J. Nutr. 136:2468-2474.

Harvatine, K. J., Y. R. Boisclair, and D. E. Bauman. 2009. Recent advances in the regulation of milk fat synthesis. Animal $3: 40$ 54.
INRA. 1989. Ruminant Nutrition: Recommended Allowances and Feed Tables. R. Jarrige ed. Institut National de la Recherche Agronomique, Paris, France.

Kennelly, J. J. 1996. The fatty acid composition of milk fat as influenced by feeding oilseeds. Anim. Feed Sci. Technol. 60:137-152.

Kim, K. H. 1997. Regulation of mammalian acetyl-coenzyme A carboxylase. Annu. Rev. Nutr. 17:77-99.

Loor, J. J., A. Ferlay, A. Ollier, M. Doreau, and Y. Chilliard. 2005. Relationship among trans and conjugated fatty acids and bovine milk fat yield due to dietary concentrate and linseed oil. J. Dairy Sci. 88:726-740.

Loor, J. J., W. H. Hoover, T. K. Miller-Webster, J. H. Herbein, and C. E. Polan. 2003. Biohydrogenation of unsaturated fatty acids in continuous culture fermenters during digestion of orchardgrass or red clover with three levels of ground corn supplementation. J. Anim. Sci. 81:1611-1627.

Martin, P., P. Ferranti, C. Leroux, and F. Addeo. 2003. Non-bovine caseins: Quantitative variability and molecular diversity. Pages 277-317 in Advanced Dairy Chemistry. Vol. 1: Proteins. 3rd ed. P. F. Fox and P. L. H. McSweeney, ed. Kluwer Academic/Plenum Publishers, New York, NY.

Martin, P. M. Szymanowska, L. Zwierzchowski, and C. Leroux. 2002 The impact of genetic polymorphisms on the protein composition of ruminant milks. Reprod. Nutr. Dev. 42:433-459.

Murphy, J. J., G. P. McNeill, J. F. Connolly, and P. A. Gleeson. 1990. Effect on cow performance and milk fat composition of including full fat soyabeans and rapeseeds in the concentrate mixture for lactating dairy cows. J. Dairy Res. 57:295-306.

Ollier, S., C. Robert-Granie, L. Bernard, Y. Chilliard, and C. Leroux. 2007. Mammary transcriptome analysis of food-deprived lactating goats highlights genes involved in milk secretion and programmed cell death. J. Nutr. 137:560-567.

Piperova, L. S., B. B. Teter, I. Bruckental, J. Sampugna, S. E. Mills, M. P. Yurawecz, J. Fritsche, K. Ku, and R. A. Erdman. 2000. Mammary lipogenic enzyme activity, trans fatty acids and conjugated linoleic acids are altered in lactating dairy cows fed a milk fat-depressing diet. J. Nutr. 130:2568-2574.

Roy, A., A. Ferlay, K. J. Shingfield, and Y. Chilliard. 2006. Examination of the persistency of milk fatty acid composition responses to plant oils in cows given different basal diets, with particular emphasis on trans-C18:1 fatty acids and isomers of conjugated linoleic acid. Anim. Sci. 82:479-492.

Schibler, L., D. Vaiman, A. Oustry, C. Giraud-Delville, and E. P. Cribiu. 1998. Comparative gene mapping: A fine-scale survey of chromosome rearrangements between ruminants and humans. Genome Res. 8:901-915.

Shingfield, K. J., Y. Chilliard, V. Toivonen, P. Kairenius, and D. I. Givens. 2008. Trans fatty acids and bioactive lipids in ruminant milk. Adv. Exp. Med. Biol. 606:3-65.

Vandesompele, J., K. De Preter, F. Pattyn, B. Poppe, N. Van Roy, A. De Paepe, and F. Speleman. 2002. Accurate normalization of real-time quantitative RT-PCR data by geometric averaging of multiple internal control genes. Genome Biol. 3:research0034.1research0034.11. 